\title{
Granular cell tumour of the ureter: first case reported
}

\author{
Rabii Madi, MD; ${ }^{*}$ Neriman Gokden, $M D ;^{\dagger}$ Graham Greene, $M D^{*}$
}

\begin{abstract}
A 33-year-old woman presented with nonspecific, colicky pain of the left lower abdomen. Computed tomography $(\mathrm{CT})$ revealed a 2-cm mass engulfing the mid-left ureter. Ureteroscopy and biopsy revealed normal mucosa, and CT-guided biopsy of the mass was nondiagnostic. The patient underwent laparoscopic exploration. A frozen section taken from the mass revealed a granular cell tumour. We excised the whole involved portion of the ureter and performed end-to-end ureteroureteral anastamosis. The postoperative course was uneventful. Examination of a segment of resected ureter revealed a granular cell tumour diffusely infiltrating the wall of the ureter. There were no features suggesting a malignant phenotype. On follow-up, the patient was found to have developed a stricture at the anastomotic area, which was successfully treated with balloon dilatation. To our knowledge, this is the first reported case of a granular cell tumour involving the ureter.
\end{abstract}

Can Urol Assoc J 2009;3(2):156-8

\section{Résumé}

Une patiente de 33 ans présente des douleurs non spécifiques au quadrant inférieur gauche de l'abdomen rappelant des coliques. Une TDM révèle une masse de $2 \mathrm{~cm}$ englobant la portion centrale de l'uretère gauche. Une urétéroscopie et une biopsie ne révèlent aucune anomalie de la muqueuse, et une biopsie de la masse guidée par TDM n'a pas permis de poser un diagnostic. La patiente a subi un examen par laparoscopie. Des fragments congelés de la masse ont révélé une tumeur à cellules granuleuses. Une excision de la partie atteinte de l'uretère a été suivie d'une anastomose urétéro-urétérale. Aucune complication postopératoire n'a été signalée. Le rapport final de pathologie fait état d'une tumeur à cellules granuleuses s'étant infiltrée de façon diffuse dans la paroi de l'uretère. Aucune observation ne porte à croire à la présence d'un phénotype malin. Au suivi, la patiente présentait une sténose de la région de l'anastomose qu'on a pu traiter efficacement par dilatation par ballonnet. À notre connaissance, il s'agit du premier cas de tumeur à cellules granuleuses touchant l'uretère.

\section{Introduction}

A granular cell tumour is a usually benign tumour that may affect many areas of the body. Areas commonly affected are the tongue, breast and subcutaneous tissues. ${ }^{1}$ Granular cell tumours rarely affect the genitourinary system. ${ }^{2}$ We report the first case of a granular cell tumour affecting the ureter, which was successfully treated by laparoscopic excision.

\section{Case report}

A 33-year-old woman was referred to our institution because of a mass engulfing the mid-third ureter. Her initial complaint was nonspecific lower abdominal and flank pain. The patient appeared healthy and reported no significant medical problems except for uterine fibroids. She had a history of endochondroma of the distal femur, and reported having intermittent episodes of flank pain. She had no surgical history.

Contrast computed tomography $(\mathrm{CT})$ showed a 2-cm mass encasing the ureter at the level of the pelvic brim (Fig. 1). There was secondary hydronephrosis, which was treated by insertion of a double J stent.

The patient initially underwent retrograde cystoscopy, retrograde pyleography and ureteroscopy. The lumen of the ureter was narrowed, but we could not identify any intramural mass. Biopsy confirmed the presence of a normal mucosa. Likewise, a CT-guided biopsy of the ureteral mass was inconclusive.

Differential diagnosis at that time favoured retroperi-

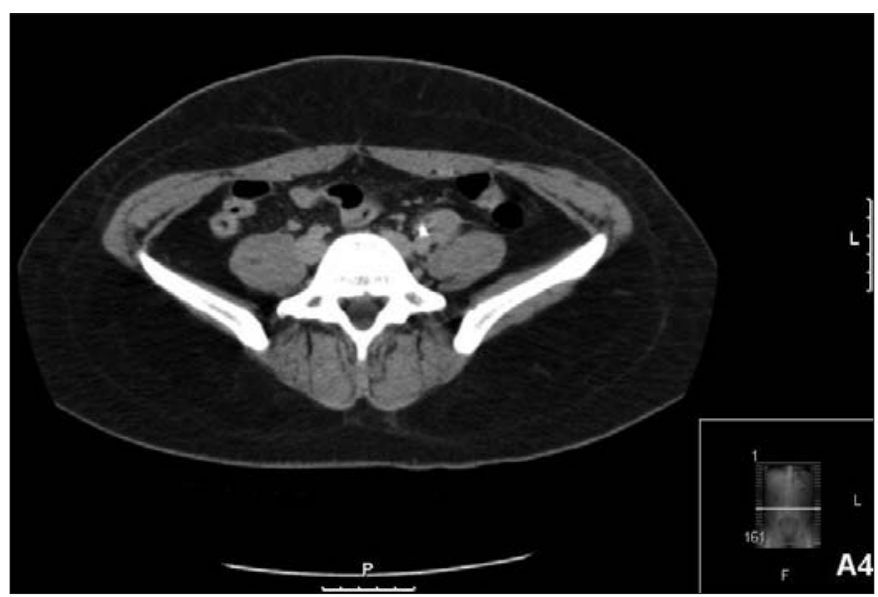

Fig. 1. Computed tomography scan showing a $2-\mathrm{cm}$ mass encasing the left ureter. 
toneal sarcoma. The patient eventually underwent laparoscopic exploration. After reflecting the bowel medially, we were able to identify the mass in the distal ureter, $1-\mathrm{cm}$ cephalad to the iliac bifurcation. The mass completely encased the ureter. Using meticulous sharp dissection, we were able to mobilize the ureter with the attached mass. Frozen section biopsy revealed a tumour resembling granular cell type. The ureter appeared stenotic even after the mass was excised. Because we were not certain of the nature of the tumour, we excised the whole portion of the ureter involved by the mass, and performed laparoscopic end-to-end ureteroureteral anastamosis using 3-0 polydioxanone in a running fashion. The anastamosis was tension-free, and we were able to obtain a good alignment of both ureteral ends. Absorbable clips (LapraTy, Ethicon Endo-Surgery) were used to secure the sutures. A new double J stent was inserted after corner sutures were secured. The total operative time was $200 \mathrm{~min}$ utes and blood loss was about $50 \mathrm{~mL}$.

The patient tolerated the procedure with no complications and she was discharged home on postoperative day 2 . The double J stent was removed 6 weeks after surgery. Follow-up CT revealed no evidence of local recurrence, but did reveal moderate hydronephrosis suggestive of anastamotic stricture. This was treated successfully with balloon dilatation. At the time of last follow-up, the patient had recovered well with no more episodes of flank pain. A MAG3 furosemide renal scan performed 2 months after the balloon dilatation showed normal renal function and excretion of the affected left kidney with a clear-

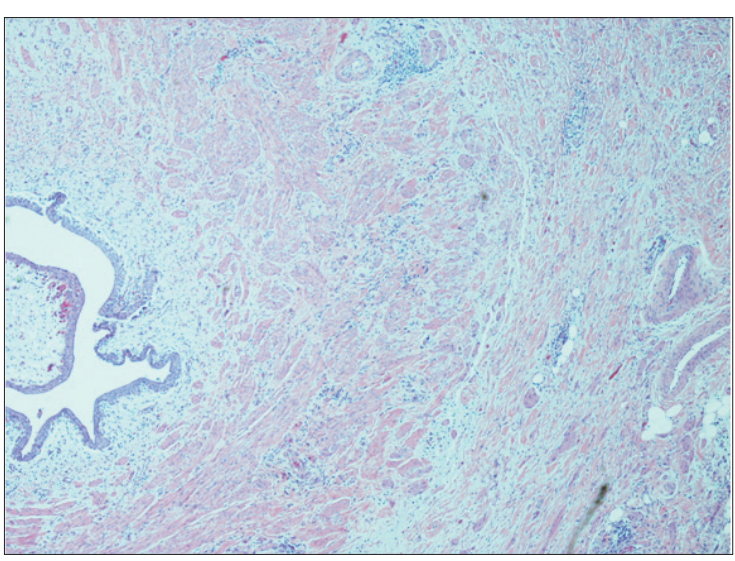

Fig. 2. Low-power view of the ureter with infiltrating tumour cells in the wall (hematoxylin-eosin stain, original magnification $\times 20$ ). ance half-time of 4 minutes and split renal function of $49 \%$.

\section{Pathology}

Morphologically, the tumour cells were either single or in small groups, infiltrating the wall of the ureter (Fig. 2). The tumour cells had large eosinophilic granular cytoplasm and small nuclei (Fig. 3). There was no increased mitotic activity, necrosis or hemorrhage. S-100 protein immunohistochemical stain showed diffuse cytoplasmic positivity in tumour cells confirming the diagnosis of granular cell tumour (Fig. 4). Less than $2 \%$ of all granular cell tumours are malignant. The histological features of malignancy include necrosis, spindling, vesicular nuclei with prominent nucleoli,

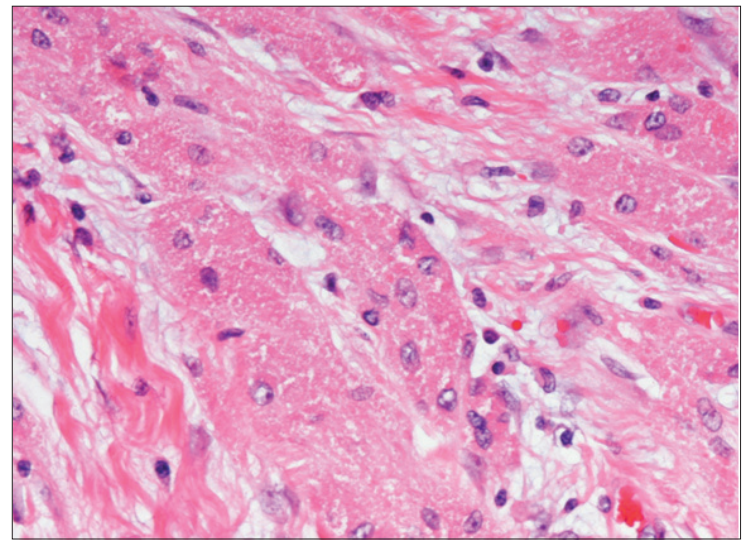

Fig. 3. High-power view of infiltrating tumour cells with abundant granular cytoplasm and small nuclei (hematoxylin-eosin stain, original magnification $\times 200$ ).

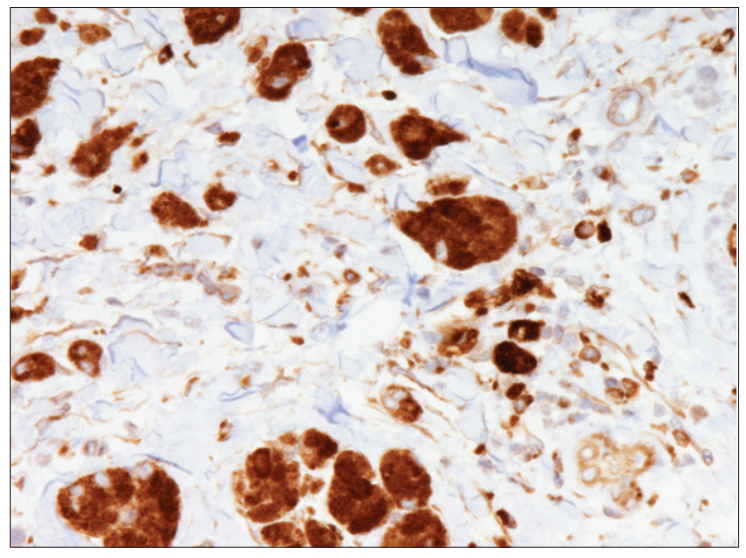

Fig. 4. Tumour cells showing diffuse and strong positivity with S-100 protein (immunoperoxidase technique, original magnification $\times 200$ ) 
Madi et al.

increased mitotic activity ( $>2$ mitoses/10 highpower field), high nucleocytoplasmic ratio and pleomorphism. Tumours with 3 or more of these features are considered malignant and have an approximate $40 \%$ risk of causing death with recurrence and distant metastases. In the case of our patient, none of these features were present.

\section{Discussion}

The granular cell tumour is believed to be a benign tumour that arises from neural cells. It was initially described by Abrikosoff in $1926 .{ }^{3}$ Involvement of the genitourinary system is rare, and there are 11 reports of granular cell tumours involving the bladder. These tumours were treated by partial cystectomy or transurethral excision. One case was treated by laparoscopic excision. ${ }^{4}$ The malignant type of granular cell tumour of the bladder has been reported in one case. ${ }^{5}$ To our knowledge, ours is the first case of granular cell tumour that involves the ureter. The growth pattern of this type of tumour is infiltrative and encasing. Full excision of the affected ureteral segment should be considered, as, in our experience, attempting to salvage the involved segment is futile and runs the risk of incomplete excision or persistent stricture. The risk of malignant behaviour is also to be considered. Minimally invasive surgery such as laparoscopy was successful in our case and can be performed depending on the tumour's location and the surgeon's expertise.

\section{Conclusion}

The granular cell tumour is a benign tumour that involves several organs of the body. There have been few reported cases of bladder involvement with this type of tumour. Ours is the first case report of a granular cell tumour involving the ureter. The tumour was managed successfully by laparoscopic excision of the ureteral segment involved and end-to-end anastamosis repair of the healthy ends.

From the *Department of Urology, Section of Genitourinary Oncology, University of Arkansas for Medical Sciences, Little Rock, Ark., and the †Department of Pathology, University of Arkansas for Medical Sciences, Little Rock, Ark.

This article has been peer reviewed.

Competing interests: None declared.

\section{References}

1. Khansur T, Balducci L, Tavassoli M. Granular cell tumor. Clinical spectrum of the benign and malignant entity. Cancer 1987;60:220-2.

2. Yoshida T, Hirai S, Horii Y, et al. Granular cell tumor of the urinary bladder. Int $J$ Urol 2001;8:29-31.

3. Abrikosoff A. Ueber Myome ausgehened von der quergestreiften willkuerlichen Muskulatur. Virchows Arch (Patho Anat) 1926;260:215-7.

4. Kondo T, Kaijmoto S, Okuda H, et al. A case of granular cell tumor of the bladder successfully managed with extraperitoneal laparoscopic surgery. Int I Urol 2006;13:827-8.

5. Ravich A, Stout AP, Ravich RA. Malignant granular cell myoblastoma involving the urinary bladder. Ann Surg 1945;121:361-72.

Correspondence: Dr. Rabii Madi, University of Arkansas for Medical Sciences, Department of Urology, Section of Genitourinary Oncology, 4301 West Markham, Slot 774, Little Rock AR 72205-7199; fax 501 603-1422; rmadi@uams.edu 